Jurnal Agro 6(2), 2019

\title{
KERAGAMAN GENETIK, FENOTIP, DAN HERITABILITAS BEBERAPA GENOTIP SORGUM PADA KONDISI TUMPANGSARI DAN MONOKULTUR
}

\section{VARIANCES OF GENETIC, PHENOTYPE, AND HERITABILITY OF SORGHUM IN INTERCROPPING AND MONOCULTURE CONDITIONS}

\author{
Kukuh Setiawan, Rafika Restiningtias, Setyo Dwi Utomo, Ardian, M. S. Hadi, Sunyoto, Erwin \\ Yuliadi
}

Jurusan Agroteknologi, Fakultas Pertanian, Universitas Lampung,

Jl. Prof. Soemantri Brodjonegoro, No. 1, Bandar Lampung 35145

Korespondensi: kukuhsetiawan38@gmail.com

Diterima : 28 April 2019 / Disetujui : 29 Oktober 2019

\begin{abstract}
ABSTRAK
Selain sebagai bahan pangan dan pakan, sorgum berpotensi menghasilkan nira untuk bioethanol. Beragamnya potensi hasil nira, mendorong perlunya evaluasi keragaan berbagai genotip sorgum untuk digunakan sebagai kriteria seleksi. Penelitian ini bertujuan untuk mengevaluasi produksi nira, membandingkan keragaman genetik dan fenotip pada beberapa genotip sorgum, serta menghitung heritabilitas arti luas. Penelitian dilaksanakan di Desa Sukanegara, Kecamatan Tanjung Bintang, Kabupaten Lampung Selatan dari April 2017 sampai Februari 2018. Rancangan perlakuan disusun secara strip plot dalam Rancangan Acak Kelompok Lengkap dengan tiga ulangan yang digunakan sebagai kelompok. Kondisi tumpangsari dan monokultur yang digunakan sebagai pembanding disusun secara strip plot. Sebanyak 15 genotip digunakan, yaitu GH 3, GH 4, GH 5, GH 6, GH 7, GH 13, Super 1, Super 2, Samurai 1, UPCA, Numbu, Mandau, Talaga Bodas, P/IWHP, dan P/F 5-193-C. Hasil penelitian menunjukkan bahwa genotip Talaga Bodas mempunyai kandungan nira yang cukup tinggi baik pada kondisi tumpangsari maupun monokultur yang masing-masing sebesar $144,0 \mathrm{ml}$ dan $166,0 \mathrm{ml}$. Sementara genotip Super 1 menunjukkan kandungan nira paling tinggi pada kondisi tumpangsari $(163,0 \mathrm{ml})$ dan genotip GH13 menghasilkan volume nira paling tinggi pada sistem monokultur $(183,0 \mathrm{ml})$. Nilai heritabilitas arti luas pada tinggi tanaman, nilai brix, kandungan nira, dan jumlah ruas pada sistem tanam tumpangsari dan monokultur termasuk dalam kriteria tinggi $(0,6-0,9)$. Nilai heritabilitas yang tinggi pada karakter tersebut menunjukkan bahwa faktor genetik lebih berpengaruh sehingga bisa digunakan sebagai kriteria seleksi.
\end{abstract}

Kata kunci: heritabilitas, ragam fenotip, ragam genetik

\section{ABSTRACT}

In addition to foodstuffs and feed, sorghum potentially produces "nira" for bioethanol. The varying potency of the nira results, prompting the need to evaluate the performance of various sorghum genotypes for use as selection criteria. The objectives of this study were to evaluate nira production, to compare genetics and phenotype variances of sorghum genotypes, also to ISSN : 2407-7933

Cite this as: Setiawan, K., Restiningtia, R., Utomo, S. D., Ardian., Hadi, M. S., Sunyoto. \& Yuliadi, E. (2019). Keragaman genetik, fenotipe dan heritabilitas beberapa genotype sorghum pada kondisi tumpangsari dan monokultur. Jurnal Agro, 6(2), 95-109 https://doi.org/10.15575/4568 
calculate broad sense heritability of some sorghum genotypes. This study was conducted at Desa Sukanegara, Kecamatan Tanjung Bintang, Kabupaten Lampung Selatan from April 2017 to February 2018. The experiment was designed by stripe plot in completely randomized block design with three replications used as block. The conditions of monoculture and intercropping used as comparison were arranged in stripe plot. As many as 15 genotypes used in this study i.e. GH 3, GH 4, GH 5, GH 6, GH 7, GH 13, Super 1, Super 2, Samurai 1, UPCA, Numbu, Mandau, Talaga Bodas, P/IWHP, and P/F 5-193-C. The result showed that Talaga Bodas genotype had high volume of nira content under monoculture and intercropping conditions as $144.0 \mathrm{ml}$ and $166.0 \mathrm{ml}$, respectively. However, Super 1 genotype had high nira content $(163.0 \mathrm{ml})$ under intercropping condition and GH13 genotype had high nira content under monoculture (183.0 $\mathrm{ml}$ ). Broad sense heritability of plant height, brix value, nira content, and internode number in both intercropping and monoculture conditions was high $(0.60-0.90)$. These high heritability values mean that these characters are influenced by genetics factor and could be used as selection criteria.

Key word: genetics variance, heritability, phenotype variance,

\section{PENDAHULUAN}

Sorgum selain dapat dimanfaatkan sebagai bahan pangan dan pakan, juga berpotensi untuk dikembangkan sebagai penghasil bioetanol. Banyak varietas sorgum telah berkontribusi dengan berbagai tipe pemanfaatan seperti sorgum biji (grain sorghum), sorgum manis (sweet sorghum), sorgum untuk pakan (forage sorghum), dan sorgum untuk biomasa (biomass sorghum). Oleh karena itu, tanaman sorgum dapat dimanfaatkan baik sebagai pangan alternatif (Elkonin et al., 2018) ataupun pakan ternak (Rossi et al., 2015). Selanjutnya, Almodares dan Hadi (2009) menyatakan bahwa batang sorgum yang menghasilkan nira bisa digunakan sebagai sumber bioetanol. Hal ini berarti bahwa batang merupakan bagian vegetatif utama selain akar dan daun, karena batang merupakan bagian yang menghasilkan nira.

Penanaman sorgum secara monokultur sangat umum dilakukan karena memiliki kondisi lingkungan yang optimum sehingga dapat menghasilkan produksi yang tinggi. Namun seiring dengan perkembangan budidaya tanaman, sorgum banyak ditanam secara tumpangsari dengan tanaman lain.

Pemuliaan tanaman merupakan suatu upaya peningkatan kualitas dan kuantitas tanaman yang bertujuan untuk menghasilkan varietas yang lebih baik atau lebih unggul (Lubis et al., 2014). Beberapa peubah genetik yang dapat digunakan untuk menentukan apakah suatu peubah dapat dijadikan kriteria seleksi, diantaranya adalah ragam genetik, ragam fenotip, dan heritabilitas (Yunianti et al., 2010; Anas et al., 2015; Abraha et al., 2015). Jika ragam genetik suatu variabel tinggi maka nilai heritabiitas akan tinggi sehingga variabel tersebut bisa digunakan sebagai kriteria seleksi. Hasil penelitian Setiawan et al. (2016) melaporkan bahwa variabel tinggi tanaman dari 20 genotip sorgum menunjukkan heritabilitas tinggi sehingga bisa digunakan kriteria seleksi sorgum sebagai penghasil biomasa. Selanjutnya Satish et al. (2016) melaporkan bahwa berdasarkan analisis menunjukkan bahwa variasi genetik dalam populasi $(95 \%)$ lebih besar dibanding dengan variasi antarpopulasi (5\%). Alhajturki (2011) 
menyimpulkan bahwa penanda ISSR dapat digunakan untuk mengevaluasi diversitas genetik dan perbedaan antar varietas sorgum. Ortiz et al. (2017) melaporkan bahwa perbedaan pertukaran gas $\mathrm{CO}_{2}$ saat proses fotosintesis dikontrol oleh gen yang terletak pada kromosom 3, 4, 6, 7, dan 8 .

Dengan demikian tujuan penelitian ini adalah untuk mengevaluasi keragaan vegetatif, membandingkan keragaman genetik dan keragaman fenotip pada beberapa kandidat genotip sorgum penghasil nira, dan menghitung heritabilitas arti luas.

\section{BAHAN DAN METODE}

Penelitian dilaksanakan dari April 2017 sampai Februari 2018 di Desa Sukanegara, Kecamatan Tanjung Bintang, Kabupaten Lampung Selatan. Analisis brangkasan dilakukan di Laboratorium Agronomi, Fakultas Pertanian Universitas Lampung, Bandar Lampung. Ada 15 genotip sorgum, yaitu GH 3, GH 4, GH 5, GH 6, GH 7, GH 13, Super 1, Super 2, Samurai 1, UPCA, Numbu, Mandau, Talaga Bodas, P/IWHP, P/F 5-193$C$ yang ditanam dengan sistem tumpangsari dengan ubikayu varietas UJ5. Pupuk yang digunakan adalah $\mathrm{KCl}$, Urea, dan TSP dengan dosis berturut-turut $200 \mathrm{~kg} \mathrm{ha}^{-1}, 200$ $\mathrm{kg} \mathrm{ha}{ }^{-1}$, dan $150 \mathrm{~kg} \mathrm{ha}^{-1}$. Jarak tanam sorgum adalah $20 \mathrm{~cm} \times 80 \mathrm{~cm}$ dan ubikayu adalah $80 \mathrm{~cm} \times 100 \mathrm{~cm}$.

Alat yang digunakan pada penelitian ini adalah saprotan, SPAD 500, gelas ukur, refraktrometer, alat pemeras batang, dan kamera. Perlakuan disusun secara strip plot dalam Rancangan Acak Kelompok Lengkap (RAKL) dengan tiga ulangan yang digunakan sebagai kelompok. Model linier adalah: Yijk $=\mu+\beta i+\tau j+\varepsilon i j k$.
Variabilitas suatu karakter ditentukan dengan membandingkan nilai ragam genetik dengan nilai simpangan baku ragam genetik, yang dihitung menurut cara Anderson dan Bancroft (1952) sebagai berikut:

$\sigma \sigma_{G}^{2}=\sqrt{\frac{2}{r^{2}}\left\{\frac{\left(n_{3}\right)^{2}}{d b_{\text {genotipe }}+2}+\frac{\left(n_{5}\right)^{2}}{d b_{\text {galat }}+2}\right\}}$ dimana N3= kuadrat tengah genotip dan $\mathrm{N} 5=$ kuadrat tengah galat.

Variabilitas genetik suatu karakter berdasarkan variasi genetik $\left(\sigma_{g}^{2}\right)$ rata-rata umum ( $\mathrm{x}$ ) dan koefisien keragaman genetik (KKG). Menurut Anderson dan Brancoff (1952) dikutip oleh Lubis et al. (2014) dengan persamaan sebagai berikut:

$$
\operatorname{KKG}(\%)=\frac{\sqrt{\sigma_{g}^{2}}}{x} \times 100
$$

Variabilitas fenotipik suatu karakter ditentukan berdasarkan variasi fenotipik $\left(\sigma_{p}^{2}\right)$, rata-rata umum $(\mathrm{x})$ dan koefisien keragaman fenotipik (KKF) menggunakan persamaan berikut:

$$
\operatorname{KKF}(\%)=\frac{\sqrt{\sigma_{p}^{2}}}{x} \times 100
$$

Berdasarkan Effendy et al. (2018) suatu karakter mempunyai keluasan variasi genetik bisa berdasarkan nilai koefiesien variasi dengan rentang $0-100 \%$ kuartil, yaitu rendah $(0 \% \leq 25 \%)$, agak rendah $(25 \%$ $\leq 50 \%)$, cukup tinggi $(50 \% \leq 75 \%)$, dan tinggi $(75 \% \leq 100 \%)$. Adapun kriteria nilai heritabilitas menurut Stansfield (1988), yaitu tinggi jika $h^{2}>0.5$, sedang jika $0.2 \leq h^{2} \leq 0.5$, dan rendah jika $h^{2} \leq 0.2$. 


$$
h^{2}=\frac{\sigma_{g}^{2}}{\sigma_{p}^{2}}
$$

Menurut Sunarya et al. (2017) suatu karakter tergolong mempunyai variabilitas genetik yang luas jika ragam genetik lebih besar dari dua kali simpangan baku ragam genetiknya $\left(\sigma_{G}^{2}>2 \sigma \sigma_{G}^{2}\right)$ dan tergolong sempit jika ragam genetik lebih kecil atau sama dengan dua kali simpangan baku ragam genetiknya $\left(\sigma_{G}^{2} \leq 2 \sigma \sigma_{G}^{2}\right)$.

Variabel yang diamati pada penilitian adalah tinggi tanaman, jumlah daun, diameter batang, kehijauan daun, jumlah ruas, bobot kering batang, bobot kerimg daun, volume nira, nilai brix, panjang malai, bobot malai, bobot 1.000 butir biji, bobot biji tanaman ${ }^{-1}$. Homogenitas ragam diuji dengan menggunakan uji Bartlett dan aditivitas data diuji dengan uji Tukey. Bila kedua asumsi terpenuhi, dilakukan analisis ragam lalu dilanjutkan uji pemisahan nilai rata-rata antar-variabel dengan BNT pada taraf 5\%. Analisis data menggunakan program Minitab (Versi 17).

\section{HASIL DAN PEMBAHASAN}

Hasil penelitian menunjukkan bahwa tidak terdapat variasi nilai kuadrat tengah genotip pada kedua sistem tanam tumpangsari dan monokultur yaitu pada variabel pengamatan jumlah daun 6 dan 7 MST (Tabel 1). Hal tersebut dimungkinkan terjadi karena adanya perbedaan genotip pada kondisi tumpangsari dan monokultur. Kondisi ini sejalan dengan penelitian Sungkono et al. (2009) bahwa adanya keragaman pada hasil analisis ragam genotip yang diuji, disebabkan oleh pengaruh genotip, lingkungan, dan interaksinya. Berdasarkan hasil penelitian nilai koefisien keragaman nilai yang tinggi pada kedua sistem tanam tumpangsari dan monokultur yaitu bobot malai, bobot biji tanaman $^{-1}$, dan bobot kering daun. Dengan demikian, koefisien keragaman pada karakter tersebut memberikan peluang untuk dilakukan seleksi. Hasil ini ditunjang oleh penelitian Ratri (2014) bahwa, karakter pada kacang hijau yang memiliki keragaman yang tinggi dapat memberikan peluang besar untuk seleksi genotip. Selanjutya, Bakheit (1990) melaporkan tinggi tanaman dan bobot biji per tanaman 22 genotip sorgum menunjukkan variasi pada kondisi cekaman air.

\section{Perbedaan Nilai Rata-rata Tinggi Tanaman Pada Tumpangsari dan Monokultur}

Hasil penelitian menunjukkan bahwa terdapat perbedaan pada hasil pemisahan nilai rata-rata pada tinggi tanaman pada kondisi tumpangsari dan monokultur (Tabel 2). Perbedaan nilai rata-rata antar-variabel pada sistem tanam tumpangsari dan monokultur menunjukkan bahwa genotip GH 7, Super 2, dan Talaga Bodas memiliki nilai rata-rata yang konsisten tinggi pada variabel pengamatan tinggi tanaman $6,7,8$, dan 9 MST, sedangkan genotip GH 13, GH 4, Mandau, dan Samurai 1 memiliki nilai konsisten rendah pada variabel pengamatan tinggi tanaman $6,7,8$, dan 9 MST pada kedua sistem tanam. Genotip P/IWHP memiliki nilai rata-rata yang tinggi pada tinggi tanaman 7, 8, dan 9 MST hanya pada kondisi tumpangsari. Sementara pada sistem tanam monokultur, genotip GH 6 memiliki nilai rata-rata variabel pengamatan tinggi tanaman yang rendah pada 6,7 , dan 8 MST. Secara umum, genotip Talaga Bodas menunjukkan nilai tinggi tanaman tertinggi (Gambar 1). Sebaliknya, tinggi tanaman 
genotip GH13 dan Samurai merupakan yang terendah.

Perbedaan Nilai Rata-rata Jumlah Daun, Kehijauan Daun, dan Bobot Kering Daun pada Tumpangsari dan Monokultur

Perbedaan nilai rata-rata pada variabel jumlah daun 8 dan 9 MST (Tabel 3) yang memiliki nilai konsisten tinggi pada tumpangsari dan monokultur yaitu genotip GH 7 dan UPCA, sedangkan untuk nilai ratarata yang rendah untuk kedua sistem tanam yaitu genotip $\mathrm{GH}$ 13, GH 4, GH 6, dan Samurai 1. Genotip P/IWHP memiliki nilai rata-rata yang tinggi hanya pada kondisi tumpangsari, sedangkan genotip Super 2 dan Talaga Bodas memiliki nilai rata-rata yang tinggi pada kondisi monokultur.

Nilai rata-rata yang tinggi pada kehijauan daun sistem tanam tumpangsari dan monokultur terdapat pada genotip $\mathrm{GH} 3$,
Numbu, P/IWHP, Super 1, Talaga Bodas, dan UPCA, sedangkan nilai rata-rata yang rendah pada kedua sistem tanam yaitu genotip GH 13, GH 4, GH 6, P/F5-193-C, Samurai 1, Super 2. Genotip GH 5 memiliki nilai rata-rata yang tinggi pada kondisi tumpangsari. Nilai kehijauan daun yang tinggi bisa dijadikan sebagai kandidat sorgum stay green. Menurut pendapat Anami et al. (2015) bahwa tipe sorgum yang stay green cenderung tahan terhadap cekaman kering. Sementara genotip GH 7 dan Mandau memiliki nilai rata-rata yang tinggi pada kondisi monokultur.

Genotip yang memiliki nilai rata-rata bobot kering daun tinggi pada kondisi tumpangsari dan monokultur yaitu $\mathrm{GH} 3$, GH 5, Mandau, dan P/IWHP, sedangkan nilai rata-rata yang rendah terdapat pada genotip Numbu, Samurai 1, dan Super 1.

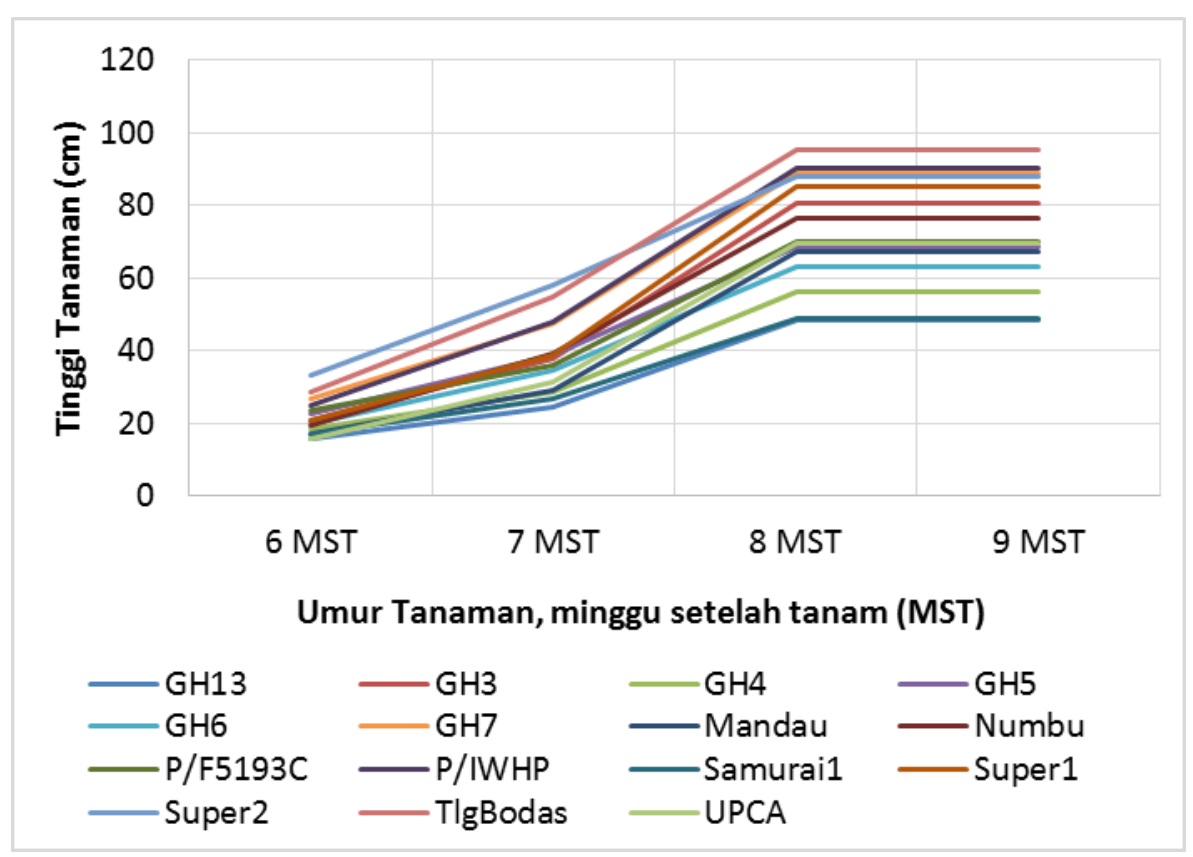

Gambar 1. Kurva petumbuhan tinggi tanaman 15 genotip sorgum (sigmoid) 
Tabel 1. Nilai kuadrat tengah beberapa kandidat genotip pada kondisi tumpangsari dan monokultur

\begin{tabular}{lcccc}
\hline \multirow{2}{*}{ Variabel } & \multicolumn{2}{c}{ Kelompok } & \multicolumn{2}{c}{ Genotip } \\
\cline { 2 - 5 } & Tumpangsari & Monokultur & Tumpangsari & Monokultur \\
\hline Tinggi tanaman 6 MST & $170,90^{*}$ & 1,43 & $224,53^{* *}$ & $3,83^{* *}$ \\
Tinggi tanaman 7 MST & $14,71^{* *}$ & 509,11 & $5,38^{* *}$ & $1531,06^{* *}$ \\
Tinggi tanaman 8 MST & $6137,30^{* *}$ & 1112,60 & $2524,00^{* *}$ & $6099,40^{* *}$ \\
Tinggi tanaman 9 MST & $6466,10^{* *}$ & $2680,40^{*}$ & $4072,80^{* *}$ & $8979,40^{* *}$ \\
Jumlah daun 6 MST & $55,47^{* *}$ & $97,36^{* *}$ & 0,96 & 0,50 \\
Jumlah daun 7 MST & $33,10^{* *}$ & $39,67^{* *}$ & 0,83 & 1,22 \\
Jumlah daun 8 MST & $28,07^{* *}$ & $110,02^{* *}$ & $2,02^{* *}$ & $3,64^{* *}$ \\
Jumlah daun 9 MST & $59,39^{* *}$ & $114,99^{* *}$ & $5,93^{* *}$ & $6,09^{* *}$ \\
Diameter batang & $128,74^{* *}$ & $55,25^{* *}$ & $11,03^{* *}$ & 10,82 \\
Kehijauan daun & $284,20^{* *}$ & 24,81 & $97,11^{* *}$ & $100,27^{* *}$ \\
Jumlah ruas & $12,81^{* *}$ & $23,89^{* *}$ & $16,23^{* *}$ & $22,35^{* *}$ \\
Bobot kering batang & 1,40 & 545,90 & $8,26^{* *}$ & $1865,90^{* *}$ \\
Bobot kering daun & $417,92^{* *}$ & $422,68^{* *}$ & $116,56^{* *}$ & $90,58^{* *}$ \\
Nilai brix & $69,14^{* *}$ & $44,51^{* *}$ & $32,37^{* *}$ & $28,09^{* *}$ \\
Kandungan nira & $3130,40^{* *}$ & $16393,90^{* *}$ & $9221,26^{* *}$ & $14314,70^{* *}$ \\
Panjang malai & 25,72 & $63,02^{*}$ & $55,08^{* *}$ & $136,51^{* *}$ \\
Bobot malai tanpa biji & $20,06^{*}$ & $7,46^{* *}$ & $10,73^{*}$ & $1,11^{* *}$ \\
Bobot malai & $2246,70^{* *}$ & 296,60 & 589,70 & $1070,80^{* *}$ \\
Bobot biji tanaman -1 & $2119,80^{* *}$ & 582,20 & 475,30 & $756,30^{* *}$ \\
Bobot biji 300 butir & 2,30 & $10,18^{*}$ & $6,75^{* *}$ & $9,51^{* *}$ \\
\hline
\end{tabular}

Keterangan: ${ }^{* *}$ : Sangat nyata pada taraf $\alpha 1 \%{ }^{*}$ : Nyata pada taraf $\alpha 5 \%$

Tabel 2. Rata-rata variabel tinggi tanaman beberapa kandidat genotip sorgum pada kondisi tumpangsari dan monokultur

\begin{tabular}{|c|c|c|c|c|c|c|c|c|}
\hline \multirow{3}{*}{ Genotip } & \multicolumn{8}{|c|}{ Tinggi tanaman $(\mathrm{cm})$} \\
\hline & \multicolumn{2}{|c|}{$6 \mathrm{MST}$} & \multicolumn{2}{|c|}{$7 \mathrm{MST}$} & \multicolumn{2}{|c|}{$8 \mathrm{MST}$} & \multicolumn{2}{|c|}{$9 \mathrm{MST}$} \\
\hline & TS & MK & TS & MK & TS & $\mathrm{MK}$ & TS & MK \\
\hline GH13 & $15,7 f$ & $16,3 \mathrm{de}$ & $24,3 f$ & $21,7 \mathrm{gh}$ & $48,3 g$ & $41,7 \mathrm{~g}$ & $56,1 \mathrm{~g}$ & $56,1 \mathrm{gh}$ \\
\hline $\mathrm{GH} 3$ & $20,8 c-f$ & $20,6 c d$ & $37,7 \mathrm{bcd}$ & 37,9def & $80,7 b-e$ & $86,4 \mathrm{bcd}$ & $98,4 a-d$ & $108 \mathrm{cde}$ \\
\hline GH4 & $18,3 \mathrm{def}$ & 19,1 cde & 28,4 def & $25,4 f-h$ & $55,9 f g$ & $49,7 \mathrm{fg}$ & $65,2 \mathrm{fg}$ & $59,6 \mathrm{gh}$ \\
\hline GH5 & $22,8 b-e$ & $23,7 b c$ & $38,7 \mathrm{bcd}$ & $40,1 \mathrm{cde}$ & $68,8 \mathrm{def}$ & $82,6 \mathrm{~cd}$ & 79,8def & 102de \\
\hline GH6 & 20,0 def & $17,4 \mathrm{cde}$ & $34,4 \mathrm{de}$ & $26,4 \mathrm{fgh}$ & 63,0 efg & $53,9 \mathrm{efg}$ & $76,6 \mathrm{efg}$ & $77,8 f g$ \\
\hline GH7 & $26,8 a b c$ & $30,6 a b$ & $47,6 a b$ & $51,3 a b c$ & $88,8 a b c$ & $112 a$ & 111,9ab & $145 a$ \\
\hline Mandau & $17,1 \mathrm{ef}$ & $18,2 \mathrm{cde}$ & 29,2 def & $26,8 \mathrm{fgh}$ & $67,2 \mathrm{~d}-\mathrm{g}$ & $52,8 f g$ & $76,9 \mathrm{~d}-\mathrm{g}$ & $71,2 \mathrm{fgh}$ \\
\hline Numbu & 19,3 def & $16,4 \mathrm{de}$ & $39,0 \mathrm{bcd}$ & 31,9 efg & $76,4 b-e$ & $73,8 \mathrm{de}$ & $94,2 \mathrm{~b}-\mathrm{e}$ & $88,1 \mathrm{ef}$ \\
\hline P/F5-193-C & $23,6 b-e$ & $15,6 \mathrm{de}$ & $35,9 \mathrm{~cd}$ & $23,5 \mathrm{gh}$ & $70,0 c-f$ & $50,7 f g$ & $86,5 c-f$ & $71,8 \mathrm{fgh}$ \\
\hline P/IWHP & $24,7 \mathrm{bcd}$ & $20,2 \mathrm{~cd}$ & $47,9 a b c$ & $42,7 b-e$ & $90,4 a b$ & $85,5 \mathrm{bcd}$ & $116,2 a$ & $117 \mathrm{bcd}$ \\
\hline Samurai1 & $17,2 \mathrm{ef}$ & $13,7 e$ & $26,6 \mathrm{ef}$ & $18,7 \mathrm{~h}$ & $48,6 \mathrm{~g}$ & $40,9 g$ & $57,6 \mathrm{~g}$ & $51,0 \mathrm{~h}$ \\
\hline Super1 & $20,9 c-f$ & $23,7 \mathrm{bc}$ & $38,7 \mathrm{bcd}$ & $45,6 \mathrm{bcd}$ & $84,9 \mathrm{bcd}$ & $103 a b c$ & $104,1 \mathrm{abc}$ & $130 a b c$ \\
\hline Super2 & $33,0 a$ & $33,8 a$ & $57,8 a$ & $59,9 a$ & $105 a$ & $105 a b$ & $118,8 \mathrm{a}$ & $128 a b c$ \\
\hline T Bodas & $28,5 a b$ & $33,1 a$ & $54,8 a$ & $55,4 a b$ & $95,4 a b$ & $115 a$ & $117,7 a$ & $141 \mathrm{ab}$ \\
\hline UPCA & $15,6 f$ & 14,8 de & 31,5 def & $27,0 f g h$ & $69,6 c-f$ & $65,8 \mathrm{def}$ & $90,1 \mathrm{cde}$ & $85,3 e f$ \\
\hline BNT5\% & 6,54 & 0,73 & 0,85 & 12,76 & 19,44 & 20,8 & 21,52 & 24,70 \\
\hline
\end{tabular}


Tabel 3. Rata-rata variabel jumlah daun, kehijauan daun, dan bobot kering daun beberapa kandidat genotip sorgum pada kondisi tumpangsari dan monokultur

\begin{tabular}{|c|c|c|c|c|c|c|c|c|}
\hline \multirow[t]{3}{*}{ Genotip } & \multicolumn{2}{|c|}{$\begin{array}{c}\text { Jumlah daun } \\
8 \mathrm{MST}\end{array}$} & \multicolumn{2}{|c|}{$\begin{array}{c}\text { Jumlah daun } \\
9 \mathrm{MST}\end{array}$} & \multicolumn{2}{|c|}{$\begin{array}{l}\text { Kehijauan } \\
\text { daun }\end{array}$} & \multicolumn{2}{|c|}{$\begin{array}{c}\text { Bobot kering } \\
\text { Daun }\end{array}$} \\
\hline & TS & MK & TS & $\mathrm{MK}$ & TS & $\mathrm{MK}$ & TS & MK \\
\hline & \multicolumn{6}{|c|}{----------------- helai ------------------ } & \multicolumn{2}{|c|}{-------- g -------- } \\
\hline GH13 & $6,11 \mathrm{bcd}$ & 6,44de & $5,89 \mathrm{cde}$ & $6,56 \mathrm{cde}$ & $39,1 \mathrm{e}$ & $44,0 \mathrm{bcd}$ & $14,3 \mathrm{bcd}$ & $17,89 a-d$ \\
\hline GH3 & $6,22 \mathrm{bcd}$ & $6,67 \mathrm{cde}$ & $6,67 \mathrm{bcd}$ & $6,89 \mathrm{~b}-\mathrm{e}$ & $44,5 a-d$ & $51,0 a$ & $18,4 a b c$ & $15,52 a-f$ \\
\hline $\mathrm{GH} 4$ & $6,11 b c d$ & 6,33de & $5,44 \mathrm{e}$ & 6,33de & $38,9 e$ & $41,3 d$ & $18,2 \mathrm{abc}$ & $15,27 b-f$ \\
\hline GH5 & $5,89 \mathrm{~cd}$ & $6,89 b-e$ & $6,56 \mathrm{bcd}$ & $7,56 a-d$ & $44,3 a-d$ & $43,4 \mathrm{bcd}$ & $17,3 a b c$ & 17,30a-e \\
\hline GH6 & $5,89 \mathrm{~cd}$ & 6,33de & $5,78 \mathrm{de}$ & $6,56 \mathrm{cde}$ & 40,4 de & $42,0 \mathrm{~cd}$ & $17,6 a b c$ & $13,20 c-f$ \\
\hline GH7 & $6,78 a b$ & $7,56 a b c$ & 7,44ab & $8,67 a$ & $43,1 b-e$ & $47,1 \mathrm{abc}$ & $10,5 d$ & $20,07 a b$ \\
\hline Mandau & $6,22 \mathrm{bcd}$ & $6,67 \mathrm{cde}$ & $6,67 \mathrm{bcd}$ & $6,56 \mathrm{cde}$ & 42,4 cde & $46,9 a b c$ & $18,8 a b$ & $18,10 a-d$ \\
\hline Numbu & $6,22 \mathrm{bcd}$ & $6,22 \mathrm{e}$ & $6,78 \mathrm{bcd}$ & 6,33de & $47,7 a$ & $47,8 a b$ & $10,4 d$ & $12,32 \mathrm{ef}$ \\
\hline P/F5-193-C & $6,67 a b c$ & $6,22 \mathrm{e}$ & $6,67 \mathrm{bcd}$ & $6,67 \mathrm{cde}$ & $38,9 e$ & $43,0 \mathrm{bcd}$ & $19,0 a b$ & $11,81 f$ \\
\hline P/IWHP & $7,33 a$ & 7,00b-e & $8,33 a$ & $7,78 a b c$ & $47,7 a b$ & $50,5 a$ & $20,8 a$ & $18,54 a b c$ \\
\hline Samurai1 & $5,67 d$ & $6,11 \mathrm{e}$ & $5,22 \mathrm{e}$ & $6,11 \mathrm{e}$ & $38,8 \mathrm{e}$ & $44,5 \mathrm{bcd}$ & $14,2 \mathrm{bcd}$ & $13,00 \mathrm{def}$ \\
\hline Super1 & $6,89 a b$ & $7,22 \mathrm{bcd}$ & $6,56 \mathrm{bcd}$ & $8,00 a b$ & $46,9 a b c$ & $48,4 a b$ & $12,6 \mathrm{~cd}$ & $13,46 c-f$ \\
\hline Super2 & 6,89ab & $7,44 a b c$ & $6,89 b c$ & $8,00 a b$ & 42,4 cde & $41,7 \mathrm{~cd}$ & $17,5 \mathrm{abc}$ & $11,79 f$ \\
\hline T Bodas & $6,56 a b c$ & $8,22 a$ & $7,11 \mathrm{~b}$ & $8,22 a$ & $46,1 \mathrm{abc}$ & $50,1 a$ & $9,19 d$ & $19,32 a b$ \\
\hline UPCA & $6,89 a b$ & 7,67ab & $7,44 a b$ & $7,67 a b c$ & $45,3 a b c$ & $47,9 a b$ & $14,2 \mathrm{bcd}$ & $20,94 a$ \\
\hline BNT 5\% & 0,78 & 0,98 & 1,09 & 1,29 & 4,58 & 5,53 & 6,11 & 5,47 \\
\hline
\end{tabular}

Keterangan: Angka yang diikuti huruf yang sama pada kolom yang sama tidak berbeda nyata (BNT $5 \%$ ). MST = Minggu setelah tanam, TS = Tumpangsari, MK = Monokultur

Berdasarkan hasil analisis Rata-rata diameter batang, nilai brix, kandungan nira, dan bobot kering batang beberapa kandidat genotip sorgum pada sistem tumpangsari dan monokultur (Tabel 4), hanya variabel diameter batang pada sistem monokultur yang tidak berbeda nyata. Pada sistem tanam tumpangsari, diameter batang nilai rata-rata yang tinggi terdapat pada 11 genotip diantaranya GH 13, P/IWHP, dan Super 2, sedangkan nilai terendah yaitu genotip Talaga Bodas. Nilai rata-rata yang tinggi pada nilai brix sistem tanam tumpangsari dan monokultur yaitu genotip GH 6 dan nilai terendah terdapat pada genotip Talaga Bodas. Nilai rata-rata yang tinggi pada kondisi tumpangsari yaitu genotip GH 7 dan P/F5-193-C, sementara nilai rata-rata tinggi pada kondisi monokultur yaitu genotip $\mathrm{GH} 4$, P/IWHP, dan UPCA.

Nilai rata-rata tertinggi pada kandungan nira sistem tanam tumpangsari dan monokultur adalah genotip Talaga Bodas, sementara nilai rata-rata yang rendah terdapat pada genotip P/F5-193-C dan Super 2. Nilai rata-rata yang tinggi pada variabel pengamatan jumlah ruas sistem tanam tumpangsari dan monokultur terdapat pada genotip P/F5-193-C, dan nilai rata-rata yang rendah pada kedua sistem tanam terdapat pada genotip GH 3, Samurai 1, dan UPCA. Nilai rata-rata tinggi pada bobot kering batang sistem tanam tumpangsari dan monokultur yaitu pada genotip GH 13, GH 5, GH 6, GH 7, dan Super 2 , dan nilai rata-rata rendah pada kedua sistem tanam terdapat pada genotip Samurai 1 dan UPCA. 
Tabel 4. Rata-rata diameter batang, nilai brix, kandungan nira, dan bobot kering batang beberapa kandidat genotip sorgum pada kondisi tumpangsaridan monokultur

\begin{tabular}{|c|c|c|c|c|c|c|c|c|}
\hline \multirow[t]{2}{*}{ Genotip } & \multicolumn{2}{|c|}{$\begin{array}{c}\text { Diameter } \\
\text { batang }\end{array}$} & \multicolumn{2}{|c|}{ Nilai brix } & \multicolumn{2}{|c|}{ Kandungan nira } & \multicolumn{2}{|c|}{$\begin{array}{c}\text { Bobot kering } \\
\text { batang }\end{array}$} \\
\hline & TS & MK & TS & MK & TS & MK & TS & MK \\
\hline & \multicolumn{2}{|c|}{------ cm ------- } & & & \multicolumn{2}{|c|}{------- ml --------- } & \multicolumn{2}{|c|}{--------- g --------- } \\
\hline GH13 & $13,7 a$ & 14,6 & $8,93 \mathrm{ef}$ & $10,3 \mathrm{~cd}$ & $98,0 f$ & $183 a$ & $59,9 a b$ & $70,9 a b$ \\
\hline GH3 & $12,7 a-d$ & 14,4 & $7,87 \mathrm{fg}$ & 9,30def & $130 \mathrm{bc}$ & 112 de & $42,1 \mathrm{a}-\mathrm{e}$ & $44,9 \mathrm{de}$ \\
\hline $\mathrm{GH} 4$ & $13,4 a b$ & 14,9 & 9,80 cde & $12,0 a$ & $103 \mathrm{def}$ & $137 \mathrm{bcd}$ & 43,1a-e & $48,3 \mathrm{cde}$ \\
\hline GH5 & $12,9 a-d$ & 14,1 & 9,03def & 10,0 cde & $102 \mathrm{ef}$ & $133 c d$ & $52,7 \mathrm{ab}$ & $69,6 a b c$ \\
\hline GH6 & 11,9a-e & 11,3 & $10,7 a b c$ & $12,3 a$ & $123 \mathrm{~b}-\mathrm{e}$ & 98,0def & $44,7 a-e$ & 57,5a-e \\
\hline GH7 & 11,9a-e & 14,5 & $11,3 a b$ & 8,87efg & $128 \mathrm{bcd}$ & $178 a b$ & $49,6 a b c$ & $71,2 a b$ \\
\hline Mandau & $13,2 a b c$ & 14,3 & $10,4 b c$ & $7,49 \mathrm{hi}$ & $105 c-f$ & $112 \mathrm{de}$ & $32,4 c-f$ & 60,3a-e \\
\hline Numbu & $12,3 a-d$ & 12,4 & 7,2ghi & 7,58ghi & $133 b$ & $173 a b c$ & $39,9 b-e$ & $55,9 b-e$ \\
\hline P/F5-193-C & $12,6 a-d$ & 12,6 & $11,8 \mathrm{a}$ & $7,34 i$ & $38,7 \mathrm{~g}$ & $52,7 \mathrm{~g}$ & $58,0 \mathrm{ab}$ & $53,8 b-e$ \\
\hline P/IWHP & $13,6 a$ & 12,1 & 8,80 ef & $11,8 a b$ & $134 b$ & $134 \mathrm{~cd}$ & $60,6 a$ & $54,1 b-e$ \\
\hline Samurai1 & $10,9 \mathrm{de}$ & 13,1 & $7,53 \mathrm{gh}$ & $10,3 c d$ & $124 b-e$ & 84,0 efg & $21,2 f$ & $21,2 f$ \\
\hline Super1 & $11,5 b-e$ & 13,9 & 6,63hij & $8,70 f g h$ & $163 a$ & $136 \mathrm{~cd}$ & $32,0 c-f$ & 65,3a-e \\
\hline Super2 & $13,7 a$ & 13,3 & $10,1 \mathrm{bcd}$ & $10,6 \mathrm{bcd}$ & $58,7 \mathrm{~g}$ & $64,7 f g$ & $45,6 a-d$ & $78,7 a$ \\
\hline T Bodas & $10,1 \mathrm{e}$ & 14,0 & $5,60 \mathrm{j}$ & $7,18 \mathrm{i}$ & $144 a b$ & $166 a b c$ & $27,6 \mathrm{ef}$ & 66,4a-e \\
\hline UPCA & $11,2 \mathrm{cde}$ & 14,6 & $6,27 i j$ & $11,3 a b c$ & $96,0 f$ & 118de & 29,5 def & $43,3 \mathrm{ef}$ \\
\hline BNT 5\% & 2,05 & & 1,16 & 1,29 & 24,67 & 40,87 & 1,39 & 22,25 \\
\hline
\end{tabular}

Keterangan: Angka yang diikuti huruf yang sama pada kolom yang sama tidak berbeda nyata (BNT 5\%). MST = Minggu setelah tanam, TS = Tumpangsari, $\mathrm{MK}=$ Monokultur

Perbedaan Nilai Rata-rata Panjang Malai, Bobot Malai Tanpa Biji, Bobot Malai, Bobot Biji Tanaman ${ }^{-1}$, dan Bobot Biji 300 Butir Pada Tumpangsari dan Monokultur

Pada variabel pengamatan panjang malai kondisi sistem tanam tumpangsari dan monokultur, nilai rata-rata yang tinggi terdapat terdapat pada genotip GH 13 dan Samurai 1 (Tabel 5), sedangkan nilai ratarata yang rendah dihasilkan genotip $\mathrm{GH} 3$, P/F5-193-C, P/IWHP, Super 2, dan UPCA (Tabel 8). Nilai rata-rata yang tinggi pada variabel bobot malai tanpa biji pada sistem tanam tumpangsari dan monokultur terdapat pada genotip $\mathrm{GH} 3, \mathrm{GH} 7$, dan $\mathrm{P} / \mathrm{IWHP}$, serta nilai rata-rata yang rendah terdapat pada genotip GH 6, P/F5-193-C, dan Super 2.
Variabel pengamatan bobot malai pada sistem tanam tumpangsari tidak berpengaruh nyata. Sedangkan pada sistem tanam monokultur nilai rata-rata yang tinggi terdapat pada 6 genotip, namun yang tertinggi yaitu genotip $\mathrm{GH} 3$ dan Talaga Bodas. Bobot biji tanaman ${ }^{-1}$ tidak berpengaruh nyata pada sistem tanam tumpangsari. Sementara pada sistem tanam monokultur nilai rata-rata yang tinggi terdapat pada 7 genotip, dimana nilai tertinggi yaitu GH 3 dan Talaga Bodas. Nilai rata-rata tinggi bobot biji 1.000 butir pada kedua sistem tanam dihasilkan genotip GH 3, Numbu, P/IWHP, dan Talaga Bodas. Sedangkan nilai rata-rata rendah pada kedua sistem tanam terdapat pada genotip 
GH 13, GH 4, P/F5-193-C, Samurai 1, Super 1, dan Super 2.

Berdasarkan hasil yang diperoleh, genotip Talaga Bodas pada kondisi tumpangsari dan monokultur lebih efisien digunakan sebagai sorgum penghasil nira dan biji karena memiliki nilai rata-rata tinggi tanaman, kehijauan daun, kandungan nira, dan bobot 1.000 butir biji yang tinggi. Hal tersebut menunjukkan bahwa fotosintat yang dihasilkan oleh tanaman pada proses fotosintesis didistribusikan untuk pembentukan batang dan malai. Genotip
GH 3 dan P/IWHP pada kondisi tumpangsari dan monokultur efisien digunakan sebagai sorgum penghasil biji karena memiliki nilai rata-rata bobot biji 1.000 butir, bobot malai tanpa biji, bobot kering daun, dan kehijauan daun yang tinggi, namun memiliki jumlah ruas dan panjang malai yang rendah. Berdasarkan penelitian Fatmawati \& Yasin (2016), diketahui bahwa untuk kegiatan seleksi dalam menghasilkan varietas terdapat galur 15103-A yang hasil bijinya lebih tinggi dari varietas yang telah dilepas yaitu varietas Numbu.

Tabel 5. Rata-rata variabel panjang malai, bobot malai tanpa biji, bobot malai, bobot biji tanaman $^{-1}$, dan bobot biji 300 butir beberapa kandidat genotip sorgum pada kondisi tumpangsari dan monokultur

\begin{tabular}{|c|c|c|c|c|c|c|c|c|}
\hline \multirow[t]{2}{*}{ Genotip } & \multicolumn{2}{|c|}{$\begin{array}{l}\text { Panjang } \\
\text { malai }(\mathrm{cm})\end{array}$} & \multicolumn{2}{|c|}{$\begin{array}{c}\text { Bobot } \\
\text { malai }(\mathrm{g})\end{array}$} & \multicolumn{2}{|c|}{$\begin{array}{c}\text { Bobot biji } \\
\operatorname{tanaman}^{-1}(\mathrm{~g})\end{array}$} & \multicolumn{2}{|c|}{$\begin{array}{c}\text { Bobot biji } \\
1.000 \text { butir (g) }\end{array}$} \\
\hline & TS & MK & TS & MK & TS & $\mathrm{MK}$ & TS & $\mathrm{MK}$ \\
\hline GH13 & $24,4 a$ & $29,2 a$ & 41,6 & $40,0 b c$ & 35,87 & $36,3 \mathrm{cde}$ & $28,4 c-f$ & $27,5 \mathrm{de}$ \\
\hline GH3 & $18,3 \mathrm{cde}$ & $17,8 \mathrm{efg}$ & 55,2 & $66,4 a$ & 49,10 & $58,1 a$ & $30,7 a-e$ & $33,3 a b c$ \\
\hline $\mathrm{GH} 4$ & $24,4 a$ & 18,8 def & 34,5 & $48,1 a b c$ & 30,42 & 41,4a-e & 27,7 def & $26,4 \mathrm{e}$ \\
\hline GH5 & $21,4 a-d$ & $21,7 b-e$ & 29,2 & $47,2 \mathrm{bc}$ & 30,73 & 41,9a-e & 26,8 def & $36,0 a$ \\
\hline GH6 & $20,7 \mathrm{bcd}$ & $20,6 \mathrm{cde}$ & 44,6 & $30,5 c$ & 40,46 & $29,5 \mathrm{de}$ & $31,1 a-d$ & $28,4 \mathrm{de}$ \\
\hline $\mathrm{GH} 7$ & $19,9 \mathrm{cde}$ & 20,8 cde & 43,4 & $48,4 a b c$ & 38,60 & $41,0 b-e$ & $29,2 b-e$ & $27,3 \mathrm{de}$ \\
\hline Mandau & $21,9 a b c$ & $22,1 \mathrm{bcd}$ & 46,9 & $55,3 a b$ & 42,94 & $47,7 a b c$ & 29,6a-e & $28,7 \mathrm{cde}$ \\
\hline Numbu & $18,1 \mathrm{de}$ & $20,6 \mathrm{cde}$ & 49,0 & $42,2 b c$ & 44,45 & 35,3 cde & $34,2 a$ & $31,8 a-d$ \\
\hline P/F5-193-C & $18,4 \mathrm{cde}$ & $17,9 \mathrm{~d}-\mathrm{g}$ & 39,7 & $29,8 c$ & 28,44 & $26,8 e$ & $28,1 c-f$ & $29,1 \mathrm{cde}$ \\
\hline P/IWHP & $16,8 \mathrm{e}$ & $14,8 \mathrm{fg}$ & 53,5 & $43,6 b c$ & 46,23 & $44,2 a-d$ & $32,7 a b c$ & $36,6 a$ \\
\hline Samurai1 & $20,9 a-d$ & $25,8 a b$ & 31,0 & $48,0 \mathrm{bc}$ & 27,23 & 41,7a-e & $23,8 f$ & $26,3 e$ \\
\hline Super1 & $24,1 a b$ & $23,9 b c$ & 33,3 & $47,2 b c$ & 29,08 & $40,3 b-e$ & 27,2 def & $30,4 b-e$ \\
\hline Super2 & 19,6 cde & $18,3 \mathrm{~d}-\mathrm{g}$ & 39,3 & $33,4 c$ & 33,67 & $27,5 \mathrm{de}$ & $26,1 \mathrm{ef}$ & $27,9 \mathrm{de}$ \\
\hline T Bodas & $18,7 \mathrm{cde}$ & $19,7 \mathrm{de}$ & 32,9 & $66,6 a$ & 28,88 & $57,1 a b$ & $33,7 a b$ & $34,0 a b$ \\
\hline UPCA & $18,1 \mathrm{de}$ & $14,3 \mathrm{~g}$ & 35,4 & $46,8 \mathrm{bc}$ & 31,51 & $40,4 b-e$ & $29,9 a-e$ & $28,2 \mathrm{de}$ \\
\hline BNT 5\% & 3,69 & 4,16 & & 19,01 & & 16,83 & 1,39 & 1,43 \\
\hline
\end{tabular}

Keterangan: Angka yang diikuti huruf yang sama pada kolom yang sama tidak berbeda nyata (BNT 5\%). $\mathrm{TS}=$ Tumpangsari, $\mathrm{MK}=$ Monokultur

Perbedaan Nilai Duga Ragam Genetik dan Ragam Fenotip pada Sistem Tumpangsari dan Monokultur

Nilai duga ragam genetik dan fenotip (Tabel 6 dan 7) pada kedua sistem tanam, tumpangsari dan monokultur memiliki kriteria luas pada variabel pengamatan tinggi tanaman $6,7,8$, dan 9 MST, nilai brix, kandungan nira, dan jumlah ruas. Nilai ragam genetik dalam kriteria sempit pada kedua sistem tumpangsari dan monokultur terdapat pada variabel pengamatan jumlah 
daun $6,7,8$ MST, diameter batang, bobot malai tanpa biji, bobot malai, bobot biji tanaman $^{-1}$, dan bobot kering daun (Tabel 6). Sementara untuk variabel jumlah daun 9 MST, kehijauan daun, dan bobot kering batang sistem tanam, tumpangsari memiliki kriteria luas, namun di sistem tanam monokultur memiliki kriteria sempit. Selanjutnya variabel panjang malai dan bobot biji 300 butir sistem tanam tumpangsari memiliki kriteria ragam genetik sempit namun sistem tanam monokultur memiliki kriteria yang luas. Hal tersebut dimungkinkan karena kerapatan antar tanaman dan adanya naugan pada tumpangsari dengan ubikayu sehingga mempengaruhi pembentukan fotosintat untuk pertumbuhan.

Penelitian ini sejalan dengan penelitan Tistama et al. (2016) yang menunjukkan bahwa pertumbuhan sorgum dan kedelai normal di TBM 1, sedangkan pada perlakuan kombinasi pertumbuhan kedelai terganggu karena naungan dari tanaman sorgum. Sementara tanaman tumpangsari yang terkena cahaya menunjukkan berat kering biomassa yang tinggi, daun lebih tebal, dibandingkan tanaman yang ternaung. Nilai duga ragam fenotip pada kedua sistem tanam yaitu tumpangsari dan monokultur memiliki nilai ragam fenotip yang luas pada seluruh variabel yang diamati.

Variasi genetik bobot biji per tanaman dalam penelitian ini adalah sempit. Hasil ini bertentangan dengan penelitian Anas et al. (2015) yang melaporkan bahwa bobot biji per tanaman mempunyai variasi genetik yang luas. Perbedaan ini sangat menarik namun masih belum diketahui penyebabnya. Kemungkinan yang bisa diinformasikan adalah bahan genotip yang digunakan apakah berasal dari dalam populasi atau antar-populasi. Cox dan Frey (1984) melaporkan bahwa populasi sorgum yang berasal dari persilangan introgres dengan persilangan balik (BC) akan menghasilkan variasi genetik yang semakin besar dengan adanya BC lanjutan. Kondisi yang sama dilaporkan oleh Sinha dan Kumaravadivel (2016) bahwa variasi genetik bisa dilihat dari jarak yang lebar pada dendogram.

\section{Perbedaan Koefisien Keragaman Genetik (KKG), Koefisien Keragaman Fenotip (KKF), dan Heritabilitas Pada Tumpangsari dan Monokultur}

Hasil penelitian menunjukkan bahwa nilai koefisien keragaman genetik (KKG) pada sistem tanam tumpangsari dan monokultur untuk variabel pengamatan bobot kering daun dan nilai brix memiliki nilai KKG kriteria agak rendah $(27,20$ 36,43) (Tabel 8). Nilai KKG dengan kriteria rendah pada sistem tanam tumpangsari dan monokultur terdapat pada variabel jumlah daun 7, 8, 9 MST, diameter batang, kehijauan daun, jumlah ruas, dan bobot 1.000 butir biji $(3,16-23,46)$. Sementara untuk nilai KKG yang cukup tinggi pada sistem tanam monokultur dihasilkan variabel tinggi tanaman 7, 8, 9 MST, dan kandungan nira $(51,20-59,44)$. Nilai koefisien keragaman fenotip (KKF) pada sistem tanam tumpangsari dan monokultur menunjukkan nilai yang cukup tinggi untuk variabel pengamatan kandungan nira, bobot malai, bobot biji tanaman ${ }^{-1}(53,06$ 61,95). Kriteria KKF rendah pada sistem tanam tumpangsari dan monokultur terdapat pada variabel jumlah daun 6, 7, 8 MST, diameter batang, kehijauan daun, dan bobot biji 300 butir (14,10 - 24,12). Sementara untuk nilai KKF yang cukup tinggi pada sistem tanam tumpangsari yaitu 
variabel bobot kering daun $(52,93)$ dan bobot malai tanpa biji $(61,73)$. Nilai KKF dengan kriteria agak rendah pada sistem tanam tumpangsari terdapat pada variabel tinggi tanaman 6, 8, dan 9 MST $(45,32-$ 47,98). Nilai KKF (Tabel 8) dengan kriteria cukup tinggi sistem tanam monokultur terdapat pada variabel tinggi tanaman 7,8 , 9 MST dan bobot kering batang $(55,09$ 70,76), serta kriteria rendah pada tinggi tanaman 6 MST $(6,15)$ dan bobot malai tanpa biji $(12,65)$. Menurut Jalata et al. (2011), nilai KKF yang lebih besar daripada nilai KKG untuk berbagai karakter produksi menandakan bahwa seleksi untuk peningkatan produksi dapat dilakukan berdasarkan penampilan fenotipik karena keragaman yang muncul pada karakter tersebut banyak dipengaruhi oleh faktor lingkungan dibandingkan dengan faktor genotip, sehingga seleksi yang dilakukan pada karakter dapat menyimpang.

Tabel 6. Nilai duga ragam genetik beberapa kandidat genotip sorgum pada kondisi tumpangsari dan monokultur

\begin{tabular}{lrrlrrl}
\hline \multirow{2}{*}{ Variabel } & \multicolumn{3}{c}{ Tumpangsari } & \multicolumn{3}{c}{ Monokultur } \\
\cline { 2 - 7 } & $\sigma_{g}^{2}$ & $2 \sigma_{\sigma_{g}^{2}}$ & Kriteria & $\sigma_{g}^{2}$ & $2 \sigma_{\sigma_{g}^{2}}$ & Kriteria \\
\hline Tinggi tanaman 6 MST & 58,48 & 53,32 & Luas & 1,07 & 0,91 & Luas \\
Tinggi tanaman 7 MST & 1,51 & 1,27 & Luas & 448,04 & 362,31 & Luas \\
Tinggi tanaman 8 MST & 696,67 & 596,58 & Luas & 1867,57 & 1440,18 & Luas \\
Tinggi tanaman 9 MST & 1180,40 & 959,49 & Luas & 2759,67 & 2119,85 & Luas \\
Jumlah daun 6 MST & 0,11 & 0,25 & Sempit & 0,02 & 0,15 & Sempit \\
Jumlah daun 7 MST & 0,03 & 0,23 & Sempit & 0,16 & 0,31 & Sempit \\
Jumlah daun 8 MST & 0,44 & 0,49 & Sempit & 0,84 & 0,88 & Sempit \\
Jumlah daun 9 MST & 1,51 & 1,41 & Luas & 1,39 & 1,47 & Sempit \\
Diameter batang & 2,05 & 2,72 & Sempit & 1,44 & 2,78 & Sempit \\
Kehijauan daun & 24,33 & 23,15 & Luas & 21,71 & 24,40 & Sempit \\
Jumlah ruas & 4,75 & 3,82 & Luas & 5,88 & 5,33 & Luas \\
Bobot kering batang & 2,01 & 1,98 & Luas & 432,60 & 450,54 & Sempit \\
Bobot kering daun & 24,56 & 28,31 & Sempit & 18,71 & 22,16 & Sempit \\
Nilai brix & 10,27 & 7,60 & Luas & 8,72 & 6,63 & Luas \\
Kandungan nira & 2840,77 & 2165,89 & Luas & 4132,63 & 3390,10 & Luas \\
Panjang malai & 13,14 & 13,19 & Sempit & 38,86 & 32,36 & Luas \\
Bobot malai tanpa biji & 1,80 & 2,68 & Sempit & 0,23 & 0,27 & Sempit \\
Bobot malai & 43,73 & 159,04 & Sempit & 218,60 & 262,30 & Sempit \\
Bobot biji tanaman ${ }^{-1}$ & 41,63 & 126,60 & Sempit & 143,67 & 186,85 & Sempit \\
Bobot biji 1.000 butir & 1,50 & 1,63 & Sempit & 2,38 & 2,28 & Luas \\
\hline Keterangan: MST = Ming & & & & & &
\end{tabular}

Keterangan: MST = Minggu setelah tanam

Kriteria keragaman genetik dan fenotip sebagai berikut:

Keragaman genetik luas: $\sigma_{g}^{2} \geq 2 \sigma_{\sigma_{g}^{2}}$; Keragaman genetik sempit: $\sigma_{g}^{2} \leq 2 \sigma_{\sigma_{g}^{2}}$

Berdasarkan hasil penelitian, nilai heritabilitas pada kedua sistem tanam tumpangsari dan monokultur memiliki kriteria tinggi terdapat pada variabel pengamatan tinggi tanaman 7,8 , dan 9
MST, nilai brix, kandungan nira, dan jumlah ruas (Tabel 8). Yaqoob et al. (2015) menyimpulkan bahwa nilai heritabilitas yang tinggi akan berhubungan erat dengan kemajuan nilai genetik. Nilai heritabilitas 
dengan kriteria sedang pada sistem tumpangsari dan monokultur dihasilkan variabel jumlah daun 8 MST, jumlah daun 9 MST, diameter batang, kehijauan daun, bobot malai tanpa biji, bobot kering batang, bobot kering daun, dan bobot 1.000 butir biji. Sedangkan kriteria rendah pada kedua sistem tanam yaitu variabel jumlah daun 6
MST. Nilai heritabilitas jumlah daun termasuk rendah-sedang $(0<\mathrm{H}<0,5)$ pada penelitian ini namun bernilai tinggi pada penelitian Anas et al. (2015), yaitu $\mathrm{H}=0,83$. Kondisi nilai $\mathrm{H}$ jumlah daun yang berbeda ini kemungkinan disebabkan oleh jumlah genotip dan lokasi tanam yang berbeda.

Tabel 7. Nilai duga ragam fenotip beberapa kandidat genotip sorgum pada kondisi tumpangsari dan monokultur

\begin{tabular}{lrrlrrl}
\hline \multirow{2}{*}{ Variabel } & \multicolumn{3}{c}{ Tumpangsari } & \multicolumn{3}{c}{ Monokultur } \\
\cline { 2 - 7 } & \multicolumn{1}{c}{$\sigma_{f}^{2}$} & \multicolumn{1}{c}{$2 \sigma_{\sigma_{f}^{2}}$} & Kriteria & \multicolumn{1}{c}{$\sigma_{f}^{2}$} & \multicolumn{1}{c}{$2 \sigma_{\sigma_{f}^{2}}$} & Kriteria \\
\hline Tinggi tanaman 6 MST & 107,57 & 8,41 & Luas & 1,69 & 0,11 & Luas \\
Tinggi tanaman 7 MST & 2,35 & 0,14 & Luas & 634,99 & 32,18 & Luas \\
Tinggi tanaman 8 MST & 1130,67 & 74,33 & Luas & 2364,27 & 85,50 & Luas \\
Tinggi tanaman 9 MST & 1712,00 & 91,05 & Luas & 3459,87 & 120,53 & Luas \\
Jumlah daun 6 MST & 0,74 & 0,11 & Luas & 0,55 & 0,10 & Luas \\
Jumlah daun 7 MST & 0,76 & 0,13 & Luas & 0,90 & 0,13 & Luas \\
Jumlah daun 8 MST & 1,14 & 0,12 & Luas & 1,96 & 0,19 & Luas \\
Jumlah daun 9 MST & 2,90 & 0,24 & Luas & 3,32 & 0,33 & Luas \\
Diameter batang & 6,92 & 0,83 & Luas & 7,93 & 1,12 & Luas \\
Kehijauan daun & 48,46 & 4,13 & Luas & 56,85 & 6,05 & Luas \\
Jumlah ruas & 6,74 & 0,34 & Luas & 10,60 & 0,81 & Luas \\
Bobot kering batang & 4,25 & 0,38 & Luas & 1000,70 & 97,79 & Luas \\
Bobot kering daun & 67,45 & 7,35 & Luas & 53,15 & 5,93 & Luas \\
Nilai brix & 11,84 & 0,27 & Luas & 10,65 & 0,33 & Luas \\
Kandungan nira & 3539,71 & 119,71 & Luas & 6049,43 & 329,94 & Luas \\
Panjang malai & 28,79 & 2,68 & Luas & 58,80 & 3,43 & Luas \\
Bobot malai tanpa biji & 7,14 & 0,91 & Luas & 0,66 & 0,07 & Luas \\
Bobot malai & 502,23 & 78,53 & Luas & 633,60 & 71,44 & Luas \\
Bobot biji tanaman-1 & 392,03 & 60,01 & Luas & 468,97 & 55,99 & Luas \\
Bobot biji 1.000 butir & 3,74 & 0,38 & Luas & 4,75 & 0,41 & Luas \\
\hline Ketangan: MST = Mingus
\end{tabular}

Keterangan: MST = Minggu setelah tanam

Nilai duga heritabilitas digunakan untuk menduga bahwa suatu karakter banyak dipengaruhi oleh faktor lingkungan atau genetik. Nilai heritabilitas yang tinggi menunjukkan bahwa pengaruh faktor genetik lebih besar terhadap penampilan fenotip, dibandingkan pengaruh lingkungan. Nilai heritabilitas yang tinggi berperan dalam meningkatkan efektifitas seleksi (Syukur et al., 2009). Variabel pengamatan kandungan nira memiliki ragam genetik dan ragam fenotip luas, dan heritabilitas yang tinggi. Genotip Talaga Bodas pada kodisi tumpangsari dan monokultur memiliki nilai rata-rata yang tinggi untuk kandungan nira, sementara Super 2 memiliki nilai rata-rata 
yang rendah. Sehingga berdasarkan nilai rata-rata tersebut proses seleksi akan lebih mudah dilakukan pada genotip Talaga
Bodas untuk karakter produksi nira yang tinggi.

Tabel 8. Koefisien keragaman genetik (KKG), koefisien keragaman fenotip (KKF), dan heritabilitas beberapa kandidat genotip sorgum pada kondisi tumpangsari dan monokultur.

\begin{tabular}{|c|c|c|c|c|c|c|}
\hline \multirow{2}{*}{ Variabel } & \multicolumn{2}{|c|}{ KKG (\%) } & \multicolumn{2}{|c|}{ KKF (\%) } & \multicolumn{2}{|c|}{ Heritabilitas } \\
\hline & TS & MK & TS & MK & TS & MK \\
\hline Tinggi tanaman 6 MST & 35,37 & 4,90 & 47,98 & 6,15 & $0,5 \mathrm{~S}$ & $0,6 \mathrm{~T}$ \\
\hline Tinggi tanaman 7 MST & 3,22 & 59,44 & 4,02 & 70,76 & $0,6 \mathrm{~T}$ & $0,7 \mathrm{~T}$ \\
\hline Tinggi tanaman 8 MST & 35,58 & 57,93 & 45,32 & 65,18 & $0,6 \mathrm{~T}$ & $0,8 \mathrm{~T}$ \\
\hline Tinggi tanaman 9 MST & 38,17 & 54,98 & 45,97 & 61,56 & $0,7 \mathrm{~T}$ & $0,8 \mathrm{~T}$ \\
\hline Jumlah daun 6 MST & 6,54 & $\begin{array}{c}\text { Tidak } \\
\text { terdeteksi }\end{array}$ & 17,13 & 14,10 & $0,2 \mathrm{R}$ & $0,0 R$ \\
\hline Jumlah daun 7 MST & 3,16 & 7,02 & 14,92 & 16,57 & $0,0 R$ & $0,2 \mathrm{~S}$ \\
\hline Jumlah daun 8 MST & 10,33 & 13,33 & 16,62 & 20,40 & $0,4 \mathrm{~S}$ & $0,4 \mathrm{~S}$ \\
\hline Jumlah daun 9 MST & 18,56 & 16,36 & 25,69 & 25,32 & $0,5 \mathrm{~S}$ & $0,4 \mathrm{~S}$ \\
\hline Diameter batang & 11,58 & 8,83 & 21,25 & 20,70 & $0,3 \mathrm{~S}$ & $0,2 \mathrm{~S}$ \\
\hline Kehijauan daun & 11,44 & 10,13 & 16,14 & 16,40 & $0,5 \mathrm{~S}$ & $0,4 \mathrm{~S}$ \\
\hline Jumlah ruas & 23,00 & 23,46 & 27,40 & 31,50 & $0,7 \mathrm{~T}$ & $0,6 \mathrm{~T}$ \\
\hline Bobot kering batang & 3,33 & 36,22 & 4,84 & 55,09 & $0,5 \mathrm{~S}$ & $0,4 \mathrm{~S}$ \\
\hline Bobot kering daun & 31,94 & 27,20 & 52,93 & 45,85 & $0,4 \mathrm{~S}$ & $0,4 \mathrm{~S}$ \\
\hline Nilai brix & 36,43 & 30,54 & 39,11 & 33,75 & $0,9 \mathrm{~T}$ & $0,8 \mathrm{~T}$ \\
\hline Kandungan nira & 47,53 & 51,20 & 53,06 & 61,95 & $0,8 \mathrm{~T}$ & $0,7 \mathrm{~T}$ \\
\hline Panjang malai & 17,78 & 30,54 & 26,32 & 37,57 & $0,5 \mathrm{~S}$ & $0,7 \mathrm{~T}$ \\
\hline Bobot malai tanpa biji & 30,99 & 7,45 & 61,73 & 12,65 & $0,3 \mathrm{~S}$ & $0,4 \mathrm{~S}$ \\
\hline Bobot malai & 16,27 & 31,98 & 55,15 & 54,45 & $0,1 R$ & $0,4 \mathrm{~S}$ \\
\hline Bobot biji tanaman ${ }^{-1}$ & 18,00 & 29,52 & 55,25 & 53,34 & $0,1 \mathrm{R}$ & $0,3 \mathrm{~S}$ \\
\hline Bobot biji 1.000 butir & 13,95 & 17,06 & 22,03 & 24,12 & $0,4 \mathrm{~S}$ & $0,3 \mathrm{~S}$ \\
\hline
\end{tabular}

Keterangan: MST : Minggu setelah tanam, KKG : Koefisien keragaman genetik, KKF : Koefisien keragaman fenotip, $\mathrm{T}$ : Tinggi, $\mathrm{S}$ : Sedang, $\mathrm{R}$ : Rendah

\section{SIMPULAN}

Kesimpulan dari penelitian ini adalah:

1. Genotip Talaga Bodas menunjukkan nira yang tinggi pada tumpangsari dan monokultur masing-masing sebesar $144,0 \mathrm{ml}$ dan 166,0 $\mathrm{ml}$ dibandingkan genotip lainnya dan konsisten tinggi pada variabel tinggi tanaman $6,7,8,9$ MST. Sementara genotip Super 1 menunjukkan nira yang tinggi hanya pada tumpangsari dan genotip $\mathrm{GH} 13$ nira yang tinggi hanya pada monokultur.
2. Perbedaan keragaman genetik antara sistem tumpangsari dan monokultur terjadi pada jumlah daun 9 MST, kehijauan daun, bobot kering batang, panjang malai, dan bobot biji 1.000 butir. Keragaman genetik luas pada kedua sistem tanam terdapat pada tinggi tanaman 6, 7, 8, 9 MST, jumlah ruas, nilai brix, dan kandungan nira, karakter dengan variasi yang luas lebih dipengaruhi oleh faktor genetik. Sementara ragam fenotip luas terjadi pada seluruh variabel yang diamati. 
3. Nilai duga heritabilitas arti luas pada tinggi tanaman 7, 8, dan 9 MST, nilai brix, kandungan nira, dan jumlah ruas pada sistem tanam tumpangsari dan monokultur termasuk dalam kriteria tinggi $(0,6-0,9)$, sehingga karakter tersebut bisa digunakan sebagai kriteria seleksi.

\section{DAFTAR PUSTAKA}

Abraha, T., S.M. Githiri, R. Kasili, W. Araia, A. B. Nyende. (2015). Genetic variation among sorghum (Sorghum bicolor L. Moench) landraces from Eritrea under post-flowering drought stress conditions. Amer. J. of Plant Sciences (6): 1410-1424.

Almodares, A. and M. R. Hadi. (2009). Production of bioethanol from sweet sorghum: A review. African Journal of Agricultural Research, 4(9): 772 780.

Alhajturki, D. (2011). Genetic variation of sorghum (Sorghum bicolor L. Moench) varieties assessed by ISSR markers. Adv. in Environ. Bio, 5(11):3504-3510.

Anami S.E., Li-Min Zhang, Yan Xia, Yu-Miao Zhang, Zhi Quan Liu, and Hai-Chun. (2015). Sweet sorghum ideotypes: genetic improvement of stress tolerance. Food and Energy Security, 4(1): 3-24.

Anas, M. Rachmadi, dan Mansyur. (2015). Phenotypic and genotypic variance and heritability of stay green character among 22 elite sorghum (Sorghum bicolor (L.) Moench) genotypes. KnE Life Sci, (2): 318-325.

Anderson \& Bancroft. (1952). Statistical Theory in Researh. Mc Graw Hill Book Company. Inc. New York. $399 \mathrm{hlm}$.

Bakheit, B.R. (1990). Variability and correlations in grain sorghum genotypes (Sorghum bicolor [L.] Moench) under drought conditions at different stages of growth. J. Agron. \& Crop Sci, 164: 355-360.

Cox, T.S. \& K.J. Frey. (1984). Genetic variation for grain yield and related traits in sorghum introgression populations. Theoritical and Applied Genetic, (68), Issue 1-2, pp 145-153.

Effendy, Respatijarti, \& B.Waluyo. 2018. Keragaman genetik dan heritabilitas karakter komponen hasil dan hasil ciplukan (Physalis sp.). Jurnal Agro 5(1): 30-38

Elkonin, L., J. Italyanskaya, and Valery Panin. (2018). Genetic modification of sorghum for improved nutritional value: state of the problem and current approaches. J. of Invest. Genomics, 5(1):39-48.

Fatmawati, \& M. Yasin H.G. (2016). Karakter agronomis dan hasil beberapa galur sorgum. Buletin Penelitian Tanaman Serealia, 1(2): 33-37.

Jalata, Z., Aryana, A \& Zekele, H. 2011. Variability, heritability, and genetic advance for some yield and yield related traits in ethiopian barley (Hordeum vulgare L.) Landraces and Crosses, Int. J. Plant Breeding and Genet, 5(1): 44-45.

Lubis, K., Sutjahjo, S.H., Syukur, M., \& Trikoesoemaningtyas. (2014). Pendugaan parameter genetik dan seleksi karakter morfofisiologi galur jagung introduksi di lingkungan tanah masam. Jurnal Penelitian Pertanian Tanaman Pangan, 33(2):122-128.

Ortiz, D., Jieyun Hu, \& M.G. Salas Fernandez. (2017). Genetic architecture of photosynthesis in Sorghum bicolor under non-stress and cold stress conditions. J. of Exp. Bot, 68(16): 4545-4557. 
Ratri, T. Hapsari. (2014). Pendugaan keragaman genetik dan korelasi antara komponen hasil kacang hijau berumur genjah. Buletin Plasma Nutfah, 20(2): 51-58.

Rossi, E.S., R. Carletto, O.P. Junior, M. Neumann, \& M.V.a Faria. (2015). Genetic improvement and quality parameters of sorghum silage (Sorghum bicolor L. Moench) relation to maize silage (Zea mays L.). Brazilian J. of App. Tech. for Agric. Sci. Guarapuava-PR, 8(1): 89-98.

Satish, L., J. Shilpha, S. Pandian, A.S. Rency, P. Rathinapriya, S.A. Ceasar, M.J. Largia, A.A. Kumar, \& M. Ramesh. 2016. Analysis of genetic variation in sorghum (Sorghum bicolor (L.) Moench) genotypes with various agronomical traits using SPAR methods. Gene (15):576-581.

Setiawan, K., M Kamal, M. Syamsoel Hadi, Sungkono, \& Ibnu Maulana. (2016). Keragaan beberapa kandidat genotip sorgum sebagai penghasil biomasa. hlm 373-380. Dalam Prosiding Seminar Nasional dan Kongres 2016 Perhimpunan Agronomi Indonesia (PERAGI). Departemen Agronomi dan Hortikultura, Institut Pertanian Bogor, Bogor.

Sinha, S \& N. Kumaravadivel. (2016). Understanding genetic diversity of sorghum using quantitative traits. Scientifica Vol. 2016, Article ID 3075023, $\quad 8 \quad$ pages http://dx.doi.org/10.1155/2016/3075 023

Stansfield W.D. (1988), Theory and problems of genetics, M. C. Grow Hill Book Co. New York USA, pp.220-221
Sunarya, S. Murdaningsih H.K.N. Rostini \& Sumadi. (2017). Variabilitas genetik, kemajuan genetik dan pola klaster populasi. J. Kultivasi, 16(1): 279-286.

Sungkono., Trikoesoemanjngtyas, W. Desta, S. Didi, S. Hoeman \& M.A. Yudiarto. (2009). Pendugaan parameter genetik dan seleksi galur mutan sorgum (Sorghum bicolor (L.) Moench) di tanah masam. Jurnal Agronomi Indonesia, 37(3):220-225.

Syukur, M., S. Sujiprihati, \& R. Yunianti. (2009). Teknik Pemuliaan Tanaman. Departemen Agronomi dan Hortikultura, Fakultas Pertanian, Institut Pertanian Bogor. Bogor. 300 hlm.

Tistama, R., Cici Indriani Dalimunthe, Yan Riska Venata Sembiring, Rahmat Fauzi, Ratih Dewi Hastuti, \& Suharsono. (2016). Tumpangsari sorgum dan kedelai untuk mendukung produktivitas lahan TBM karet (Hevea Brasiliensis Muell Arg). Jurnal Penelitian Karet, 34(1) : 61-76.

Yaqoob, M., N. Hussain, and A. Rashid. (2015). Genetic variability and heritability analysis for yield and morphological traits in sorghum (Sorghum bicolor L. Moench) genotypes. J. Agric. Res., 53(3): 331343.

Yunianti, R., S. Sarsidi, S. Sujiprihati, S. Memen \& S.H. Hidayat. (2010). Kriteria seleksi untuk perakitan varietas cabai tahan Phytophthora capsici Leonian. Jurnal Agronomi Indonesia, 38(2) :122-129. 